\title{
IMPORTANCE OF APOPTOSIS MARKERS (MDM2, BCL-2 AND Bax) IN CONVENTIONAL RENAL CELL CARCINOMA
}

${ }^{1}$ A.Tsulukidze national centre of Urology, ${ }^{2}$ department of Urology, ${ }^{2}$ department of Pathology;

${ }^{3}$ Scientific and Practical Center of Clinical Pathology, Tbilisi, Georgia

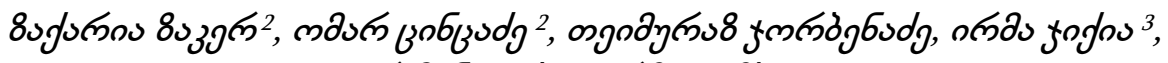

$$
\begin{aligned}
& \text { muyn aubuzudy }{ }^{1} \text {, unhom hbmoju }{ }^{1}
\end{aligned}
$$

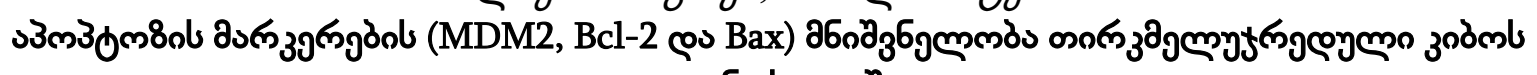

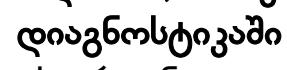

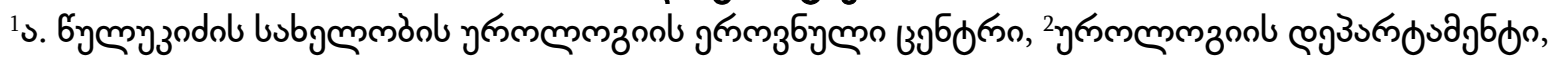

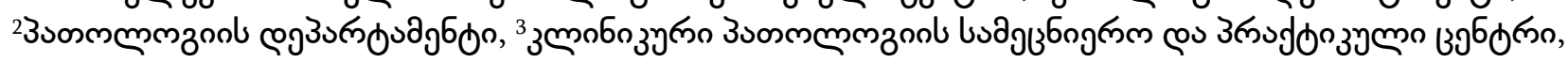

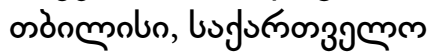

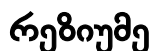

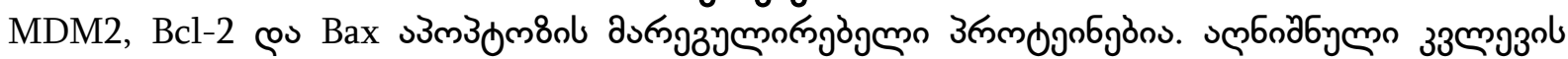

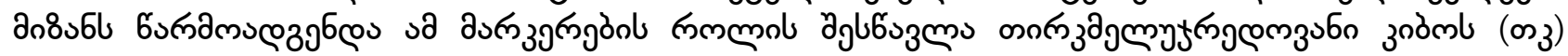

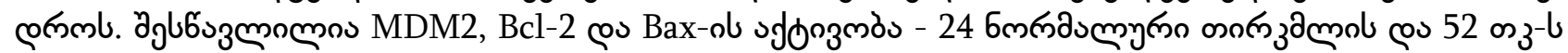



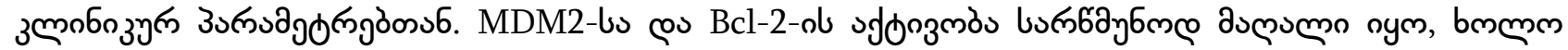

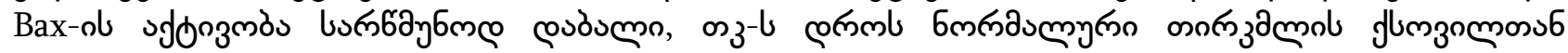

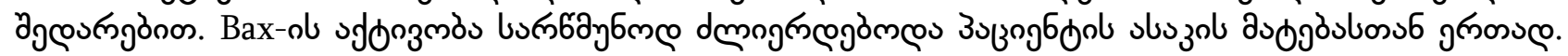

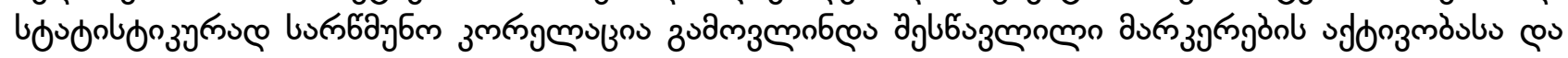

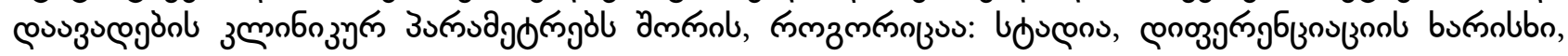

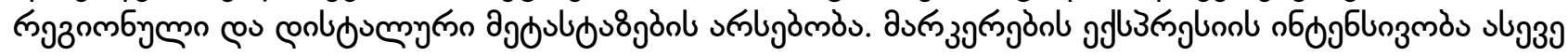

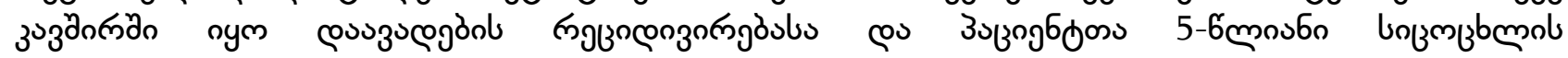

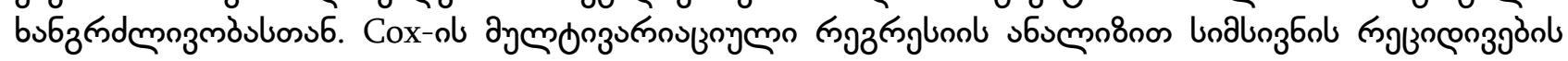

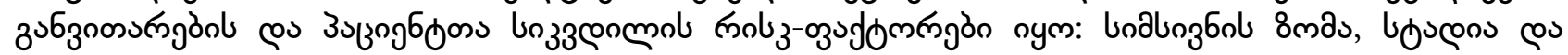
coozgr

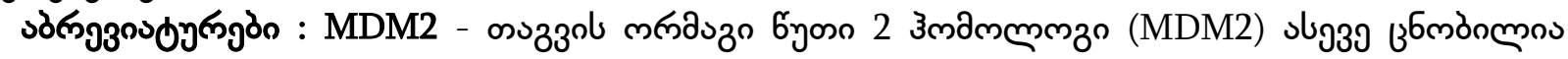
๓мзмпु E3 ubiquitin-protein ligase (Mouse double minute 2 homolog (MDM2) also known as E3

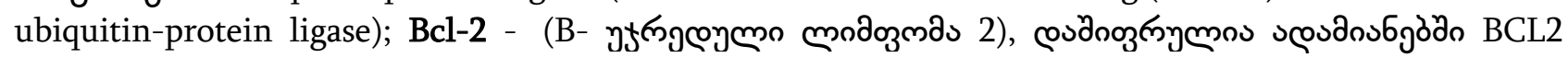
396 bngא (B-cell lymphoma 2), encoded in humans by the BCL2 gene; Bax - د3m3

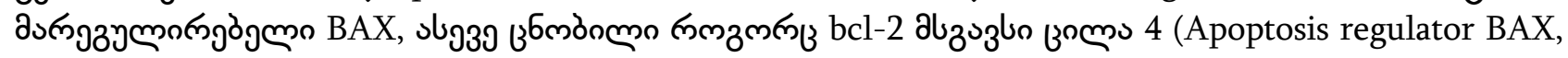

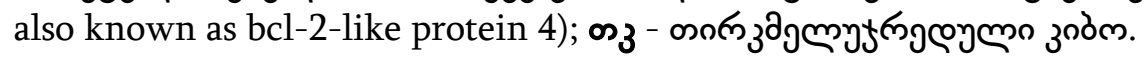

The survival rate of patients with renal cell carcinoma (RCC) has increased due to the improvements in early diagnosis and surgical treatment of the disease. Yet, 1/3 of patients with localized cancer will develop distant metastasis after radical treatment [11]. Therefore, identification of high-risk patients remains an important problem in the management of the disease. Numerous molecular and chromosomal markers have been evaluated for this purpose with no consensus regarding their significance in RCC $[3-5,10]$. Tumor stage and grade are currently recognized as independent prognostic factors of the disease. However, the assessment of tumor grade may vary substantially due to subjectivity of the observer [3,4], and the TNM classification of the disease has been recently questioned $[1,14]$. Therefore, detection of new, more sensitive and specific prognostic markers of the tumor behavior is of utmost importance.

The review of the recent literature clearly shows importance of the apoptosis markers in cancer development. Apoptosis is an essential physiological process for the selective elimination of cells that are involved in a variety of biological events. The best characterized protein family in the regulation of apoptotic cell death is Bcl-2 family. It is an anti-apoptotic protein playing extremely important role in 
cell division and death [12].

MDM2 is another anti-apoptotic protein. Its importance has been implicated in many human cancers, including: sarcomas, certain hematologic malignancies, breast, colon and prostate cancers. MDM2 over-expression has been related to more aggressive disease and poorer survival [13].

Induction of apoptosis in RCC cell lines was associated with a decrease in expression of the antiapoptotic proteins, Bcl-2 and Bcl-XL, without marked changes in the pro-apoptotic protein Bax [6]. RCC growth has been related to a significant decrease in the expression of the anti-apoptotic $\mathrm{Bcl}-2$ and increase in pro-apoptotic Bax [7]. While some studies are showing statistically significant association of Bax and Bcl-2 with patient survival [2], others didn't find association between Bcl-2, Bax and disease outcome [15].

There are limited number of clinical studies on the importance of apoptosis markers in RCC. The sorafenib and nutlin-3 co-treatment of the RCC lead to increase levels of p53, Bax, and decrease in the anti-apoptotic Bcl-2 levels [16]. Increased co-expression of p53 and MDM2 identified those patients with a significantly reduced disease-specific survival by univariate and Cox multiple regression analyses [8]. There are some other recent studies showing that: MDM2 upregulation is associated with decreased disease-specific survival, and the patients who have tumors that display both the increased p53 and MDM2 expression may have the poorest overall survival [9].

The goal of the current study was to analyze the expression of Bcl-2, MDM2 and Bax in benign and malignant renal tissue samples and assess their possible association with different clinical parameters. Prognostic significance of the markers in recurrence-free and cancer-specific survivals has also been evaluated.

\section{Materials and methods. Patient groups}

The study population consisted of 76 consecutive patients treated at our institution. The tissue samples were prospectively collected. All patients (control as well as study group) were operated in one department and all removed kidneys were sent to the department of pathology of the same institution (National Center of Urology). The same team of personnel according to the single protocol has technically processed all the tissue specimens.

The patients were divided in 2 groups: group I: 24 normal human kidney tissue samples resected from patients of different ages due to RCC (67\%) and kidney trauma (33\%); group II: 52 RCC samples received from 44 radical and 8 partial nephrectomies.

The mean age of patients in group I was $53.4 \pm 17$ years (range: $21-80$ years); 15 (63\%) were males and $9(37 \%)$ were females. The mean follow-up is 26 months (range: 2-35 months). None of the patients had clinical signs of renal insufficiency or other substantial co-morbidities (hypertension, acute or chronic pyelonephritis etc.). All of them were free of diabetes. Morphological evaluation revealed mild to moderate degree of age-associated pathological changes in 6 patients.

The mean patient age in group II was $50.8 \pm 10.9$ years (range: $20-68$ years); 25 (48\%) were males and 27 (52\%) were females. The mean follow-up is 26 months (range: 2-35 months). Radical or partial nephrectomy without adjuvant immunotherapy was performed in all patients. The pathological stage distribution of the tumors was the following: T1 - 21 (40\%); T2 - 13 (25\%); T3 - 18 (35\%).

Patients. 14 (27\%) cancers were G1, 20 (38\%) - G2 and 18 (35\%) - G3. Morphological evaluation revealed clear cell RCC in all 52 patients. 2 patients had lymph node and 1 patient had distant metastases at the time of surgery. $18(34.6 \%)$ tumors were discovered incidentally, 29 (55.8\%) were locally symptomatic and 5 patients $(9.6 \%)$ had a systemic disease symptoms. All patients were operated on in one department and all removed kidneys were sent to the department of pathology of the same institution. The same team of personnel according to the single protocol has technically processed all the tissue specimens.

Tissue sampling and immunohistochemistry. Resected kidney specimens from the patients of group I were evaluated macroscopically. After sampling according to the main disease, $1.5 \mathrm{x} 2 \mathrm{~cm}$ tissue samples were taken from 2 separate, most distant from the tumor and macroscopically normal kidney regions. The samples were fixed in $4 \%$ formaldehyde and embedded in paraffin. Four micron thick serial sections were stained with hematoxylin and eosin and analyzed by two pathologists (O.T. and Z.H.S). Only the kidneys considered normal and with acceptable age-associated morphological changes (mild 
interstitial infiltration and/or tubular atrophy) were further immunohistochemically evaluated and included in the study.

Resected kidneys from the patients of group II were evaluated macroscopically. The maximal tumor size was measured and $1.5 \times 2 \mathrm{~cm}$ tissue samples were taken for further assessment. Specimens were fixed, stained and evaluated by the same pathologist according to conventional technique. The tumors were staged according to the AJCC classification system and graded according to Fuhrman's grading system.

Four micron thick sequential tissue sections were used for immunohistochemistry. Tissue samples were deparaffinized in xylene and rehydrated in graded ethanol (50\%-70\%-96\%). Endogenous peroxidase was blocked by incubation in $1 \%$ hydrogen peroxide. Sections were pretreated by the microwave antigen retrieval procedure (4 cycles for $5 \mathrm{~min}$ each at $600-700 \mathrm{watt}$ ) in $10 \mathrm{mmol} / \mathrm{L}$ of boiling citrate buffer solution ( $\mathrm{pH}$ 6.0). The tissue sections were then incubated with primary antibodies against Bcl-2, MDM2 and Bax (Zytomed Sysytems Inc.) diluted (no dilution, 1:200 and 1:100, respectively) in phosphatebuffered saline (PBS). The tissue sections were revealed using the Biotin-Streptavadin detection system (ZytoChem Plus (HRP) kit, Zytomed Sysytems Inc.). Samples were developed with liquid diaminobenzidine + substrate-chromogen system and counterstained with haematoxylin. Human tonsil tissue was used as a positive control while antigen-free PBS as a negative control, according to the established protocols of immunohistochemical staining.

Sample scoring and statistical analysis. Slides were evaluated blindly by two of the authors (O.T. and A.C.). Intensity of nuclear expression of the markers was scored according to the following system: score 0 , no staining; score 1 , less than $30 \%$ cells positive; score $2,31-50 \%$ cells positive; and score 3 , more than $50 \%$ of cancer cells positive. Cytoplasmic staining was assessed as: score 0 , no staining; score 1 , mild staining; score 2, moderate staining; and score 3 , strong staining.

Statistical analysis was performed using computer software (SPSS 12.0 for Windows, Lead Technologies Inc. 2003. Chicago, IL.). Normality of data distribution was examined with KolmogorovSmirnov test. The kappa index for inter-observer concordance was calculated. Age-dependency of the markers' expression was analyzed by the Spearman correlation. Intensity of the markers' expression in the groups was compared with Mann-Whitney test. A possible association of the protein expression with the clinical parameters (stage, grade, disease symptoms, etc.) was analyzed with Kruskal-Wallis test. In case of significant differences, the means of data were compared with non-parametric comparison of ranks. Recurrence-free and cancer-specific survival was estimated with the Kaplan-Meier method. The prognostic value of different clinical parameters in the disease recurrence and patient death was analyzed with the log-rank test. The Cox proportional hazards model was used to define the risk factors for tumor recurrence and patient death. Stepwise selection of variables was done to determine the best predictors.

Results and their discussion. Activity of anti-apoptotic markers MDM2 and Bcl-2 were significantly higher in RCC as compared with normal kidney tissues ( $\mathrm{p}=0.0020$ and $\mathrm{p}=0.0216$, respectively) (Fig. 1) (IHC Stain Pic1,2,5,6).

In contrast, significantly higher expression of pro-apoptotic Bax has been detected in normal kidney tissues than in RCC. This difference was visible in nuclear $(\mathrm{p}=0.0205)$ as well as cytoplasmic $(\mathrm{p}=0.0209)$ activities of the marker (Fig. 2). (IHC Stain Pic3,4,7)

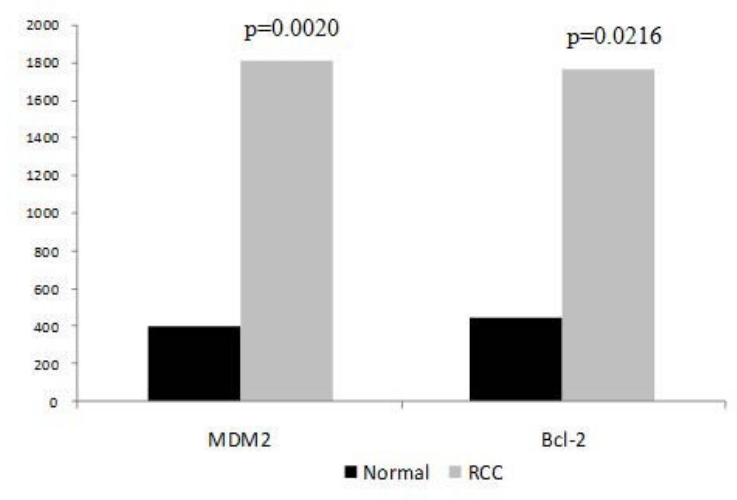

Fig. 1. Comparison of intensity of MDM2 and Bcl-2 activities between the groups 


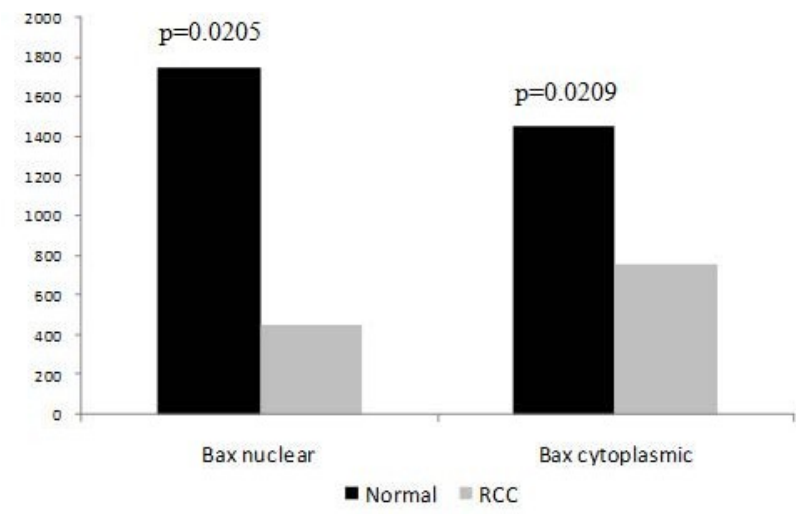

Fig. 2. comparison of intensity of nuclear and cytoplasmic

\section{Bax expressions between the groups}

Bax expression was positively correlated with patient age (Rho=0.179, p=0.0076) (Fig. 3).

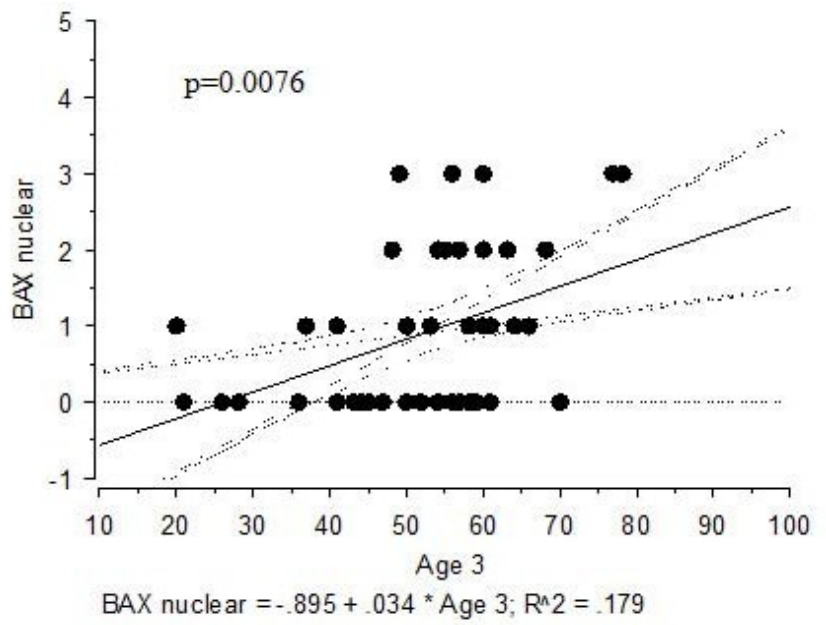

Fig. 3. Correlation of Bax activity with patient age

Significant association has been detected between the evaluated markers and cancer clinical parameters. Nuclear and cytoplasmic activity of Bax was significantly higher is stage I as compared with the stages III and IV ( $\mathrm{p}=0.0206$ and $\mathrm{p}=0.0190$, respectively) (Fig. 4). Both, nuclear and cytoplasmic activity of Bax was negatively associated with tumor grade ( $\mathrm{p}=0.0420$ and $\mathrm{p}=0.0352$, respectively) (Fig.5). The marker's expression was significantly lower in $\mathrm{N}+$ than in $\mathrm{N}$ - disease $(\mathrm{p}=0.0080)$. The MDM2activity was significantly higher in metastatic disease, as compare with non-metastatic tumors.

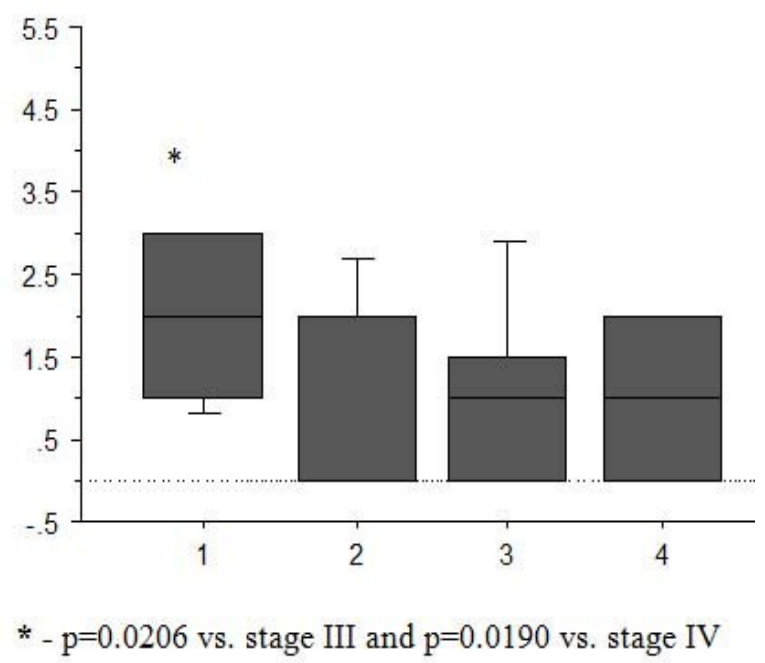

Fig. 4. expression of Bax according to tumor stage 

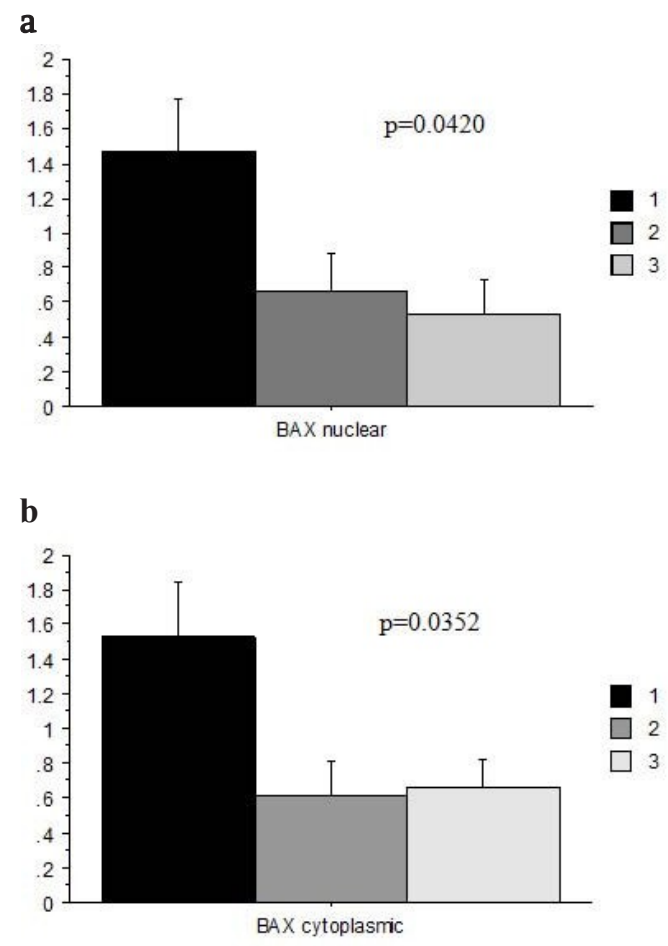

Fig. 5. Nuclear (a) and cytoplasmic (b) expression ofBax according to Furhman's grade

Interesting changes have been detected in markers' activity according to the tumor pathological features. In particular, presence of tumor necrosis was associated with significantly lower MDM2 and Bcl-2 activities (Fig. 6). Presence of microscopic vascular invasion was associated with significantly higher Bcl-2 ( $\mathrm{p}=0.0144)$ and lower Bax activities ( $\mathrm{p}=0.0439)$ (Fig. 7).

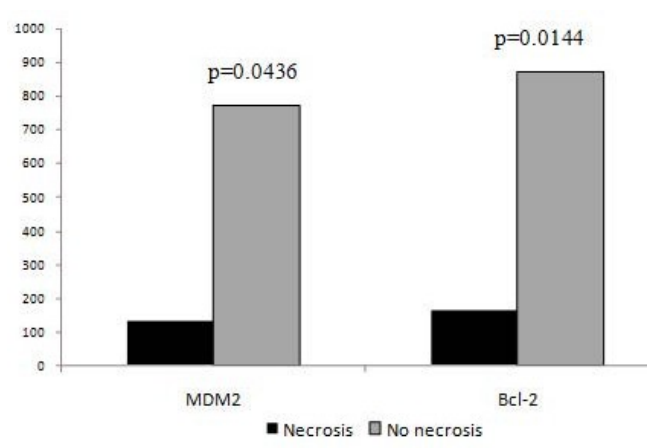

Fig. 6. Comparison of intensity of MDM2 and Bcl-2 activities according to presence of tumor necrosis

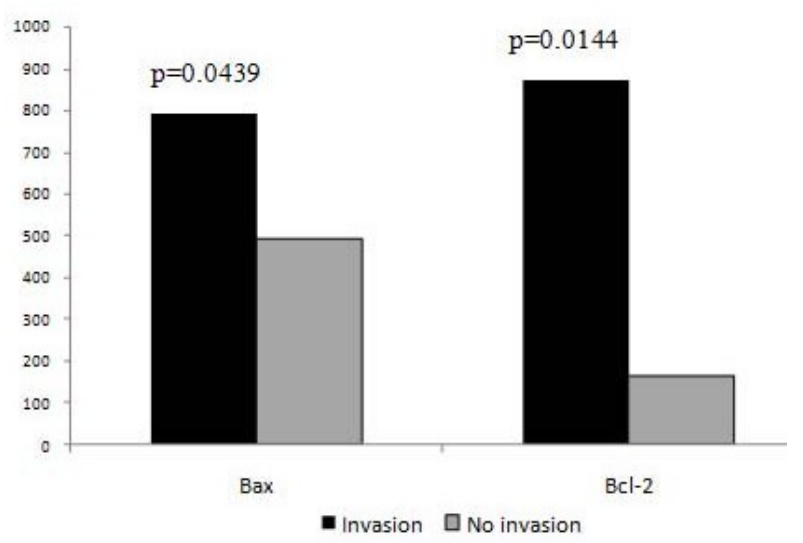

Fig. 7. Comparison of intensity of Bcl-2 and Bax activities according to presence of tumor microvascular invasion 
Expression of the markers has been associated with the clinical course of the disease. Nuclear and cytoplasmic activities of Bcl-2 were positively associated with the disease recurrence $(\mathrm{p}=0.0111$ and $\mathrm{p}=0.0115$, respectively) (Fig. 8). Moreover, time to recurrence was positively associated with Bax activity (Fig. 9). 5-year patient survival was negatively associated with nuclear $(\mathrm{p}=0.0443)$ and cytoplasmic ( $\mathrm{p}=0.0429)$ MDM2 activities (Fig. 10).

Cox multivariate regression analysis was performed to analyze the risk-factors for disease recurrence and patient death. Tumor size, pathological stage, and grade were identified as significant determinants of patient death and tumor recurrence (Table).

a

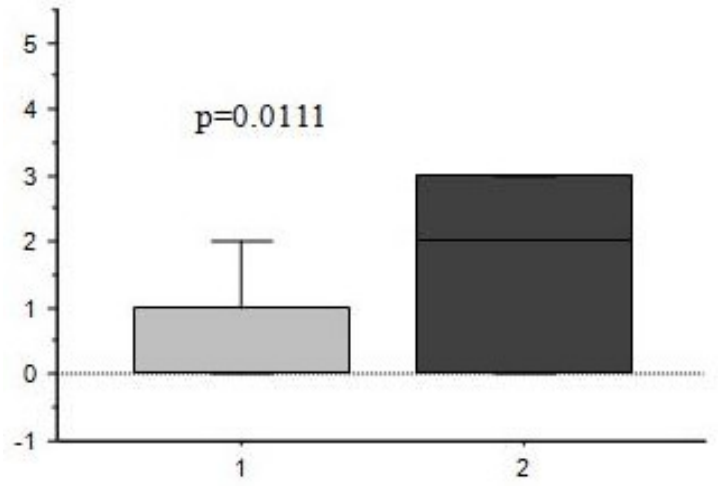

b

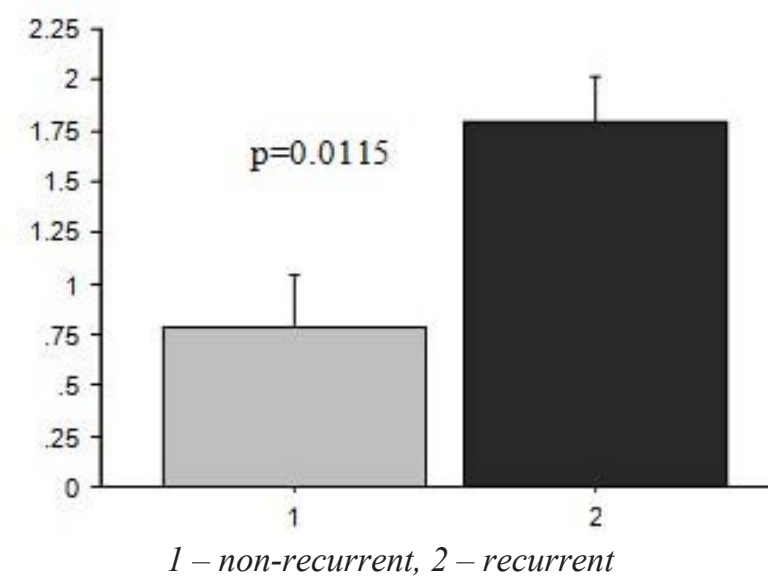

Fig. 8. Nuclear (a) and cytoplasmic (b) activity of Bcl-2according to tumor recurrence



\begin{tabular}{|c|c|c|c|}
\hline & Mean Diff. & Crit. Diff & P-Value \\
\hline 0,1 & -1.118 & 11.733 & .8460 \\
\hline 0,2 & 24.216 & 13.221 & .0009 \\
\hline 0,3 & 28.682 & 10.741 & $<.0001$ \\
\hline 1,2 & 25.333 & 16.125 & .0034 \\
\hline 1,3 & 29.800 & 14.163 & .0002 \\
\hline 2,3 & 4.467 & 15.419 & .5561 \\
\hline
\end{tabular}


a
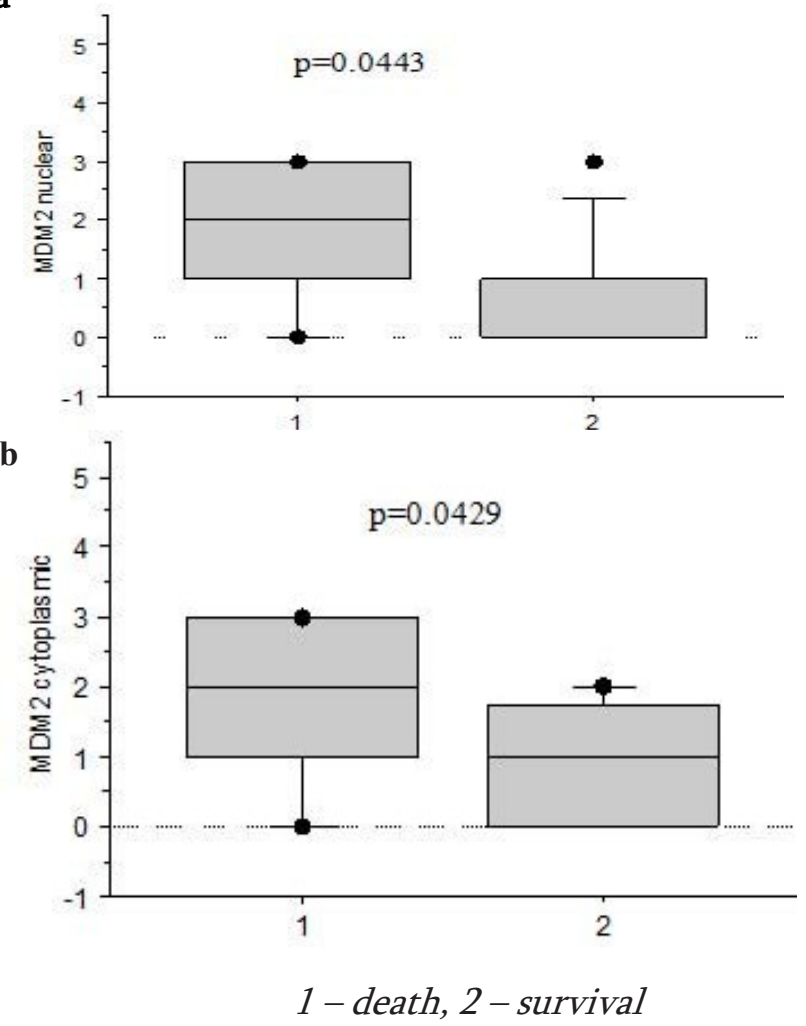

Fig. 10. Association of nuclear (a) and cytoplasmic (b) MDM2 activities with 5-year patient survival

Despite a considerable progress in understanding the basic biology of RCC, many aspects of the disease still remain unclear. This especially concerns the prognostic markers of the tumor recurrence and patient survival. The lack of markers predicting disease outcome is one of the most important problems in RCC.

With better understating of molecular biology and genetics of RCC numerous new markers have been evaluated [3-5,10]. One of the new and promising directions for future research in this area is evaluation of apoptosis markers. Dysregulation of apoptosis results in rapid cellular proliferation and is a hallmark of the cancer development.

Only few studies have evaluated the value of the markers in RCC with conflicting results. Future studies should clarify significance of the apoptosis markers in clinical practice. There are no studies evaluating combination of the above markers (Bax, MDM2 and Bcl2) in RCC. We think that it may enhance their significance as clinical markers in cancer prognosis. The results of available clinical studies are mostly controversial. A potential shortcoming of these studies is that they assessed the marker expression level qualitatively with a various cut points (10\% to $50 \%)$ of positively stained cells to predict the disease prognosis. Moreover, in all former studies the markers' expression was assessed in the whole tissue area without separating between different renal (interstitial, tubular epithelial, vascular endothelial and mesangial glomerular) cells. Thus, the question in which tissue structures expression of the proteins was clinically important remains unanswered. There are no studies evaluating the association between the markers' activity in RCC.

In the current study we found that activity of anti-apoptotic MDM2 and Bcl-2 was significantly elevated while activity of pro-necrosis and microvascular invasion. This finding is also original showing importance of apoptosis on cellular level.

Cox regression analysis has shown that tumor size, pathological stage and grade are the risk factors for disease recurrence and patient death. Although the correlation was low in this study, higher number of RCC samples should be evaluated to elucidate importance of the markers in cancer progression and growth. The significance of tumor size in cancer prognosis has been recognized in other studies, however, there is no consensus concerning the cut-off size of the tumor [4]. In our study the cut-off size of $8 \mathrm{~cm}$ was associated with the disease recurrence and cancer-related patient death. 
The primary results of this study support the value of the assessed markers in RCC and indicate the direction of future research. Further prospective studies with more patients and longer follow-up are needed in this respect apoptotic Bax was decreased in RCC as compared with normal kidney tissues. The new finding of this study is increased expression of Bax with patient age. This underlines importance of apoptosis in the process of aging. Significant association has been detected between the evaluated markers and cancer clinical parameters like: stage, grade, lymph node and distant metastasis. Interesting changes have been detected in markers' activity according to the tumor morphological features in particular, presence of tumor

Table. results of Cox multivariate regression analysis for disease recurrence and patient death

\begin{tabular}{|c|c|c|c|c|}
\hline \multirow{2}{*}{ Parameter } & \multicolumn{2}{|c|}{ Disease recurrence } & \multicolumn{2}{c|}{ Patient death } \\
\cline { 2 - 5 } & Chi-square & p value & Chi- square & p value \\
\hline Tumor size & 17.5 & $<0.0001$ & 11.44 & 0.0007 \\
\hline PT & 13.67 & 0.0011 & 9.09 & 0.0106 \\
\hline G & 6.13 & 0.0467 & 8.39 & 0.0151 \\
\hline
\end{tabular}

\section{IMMUNOSTAINING}

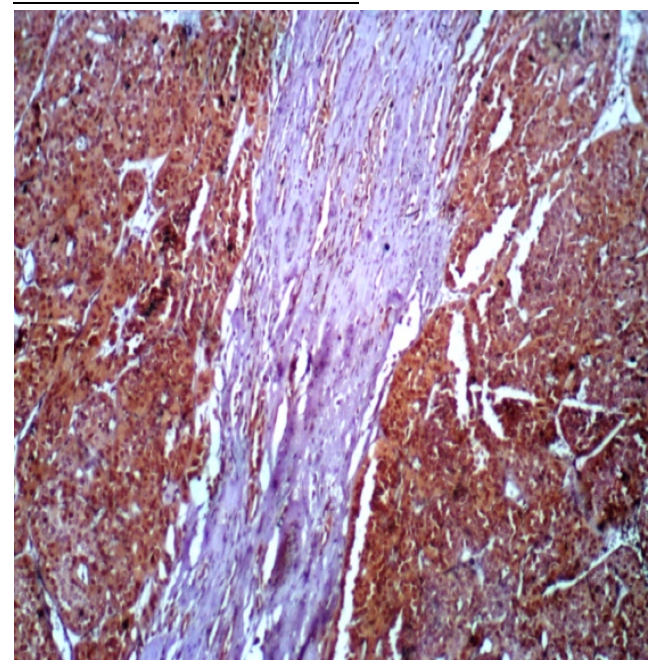

Pic. 1 Immunohistochemical staining for mdm2 protein in a grade 3 clear cell RCC



Pic. 3: Immunohistochemical staining for BAX protein in a grade 3 clear cell RCC

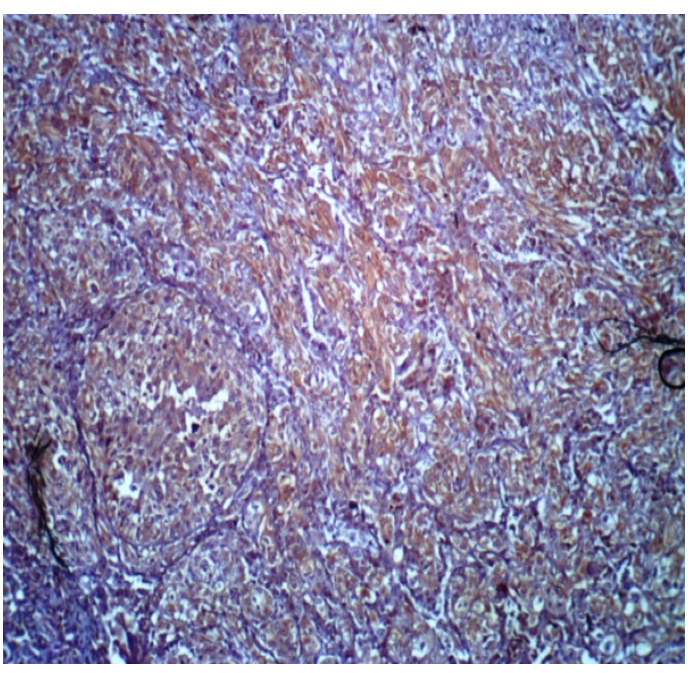

Pic. 2: Immunohistochemical staining for BCL2 protein in a grade 3 clear cell RCC

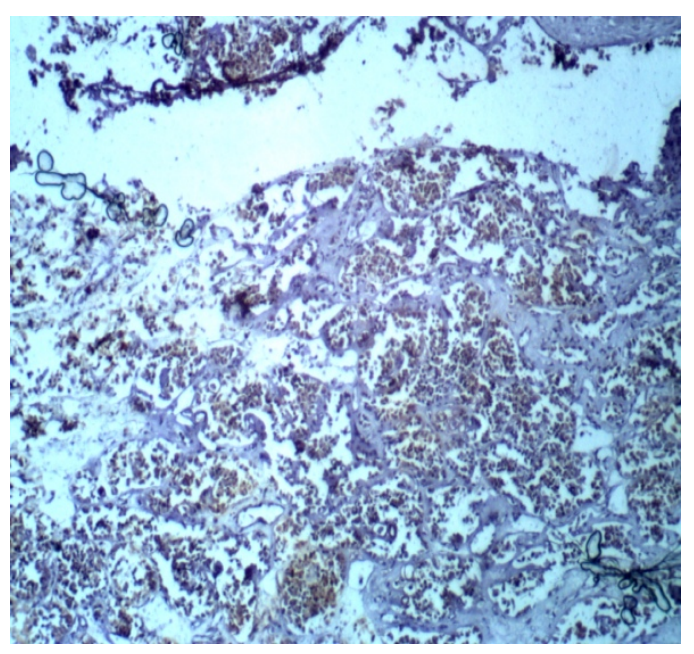

Pic. 4: Immunohistochemical staining for BAX protein in a grade 3 clear cell RCC 


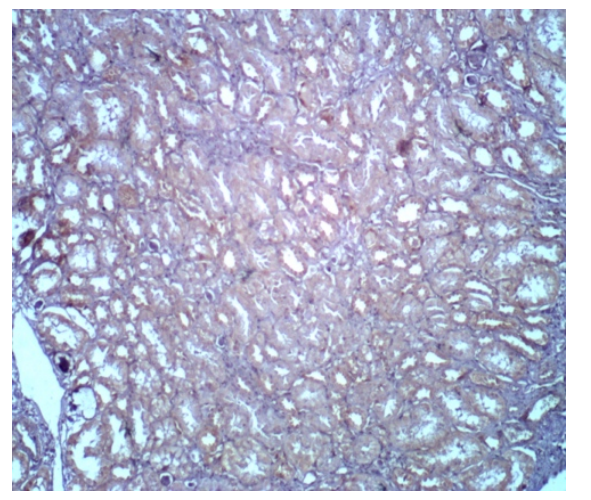

Pic.5 Immunohistochemical staining

$\mathrm{mdm} 2$ protein in a normal renal tissue

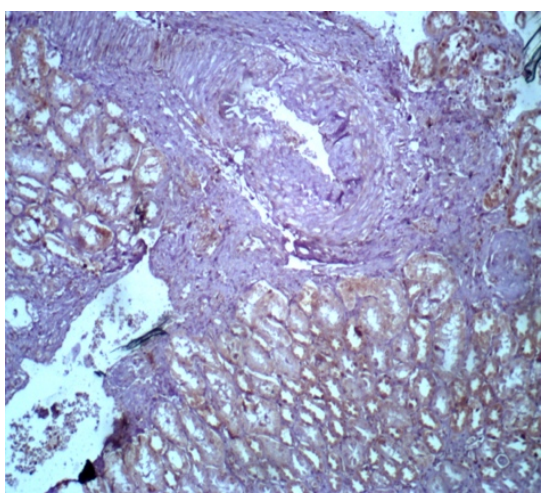

Pic.6 Immunohistochemical staining

$\mathrm{Bcl}-2$ protein in a normal renal tissue

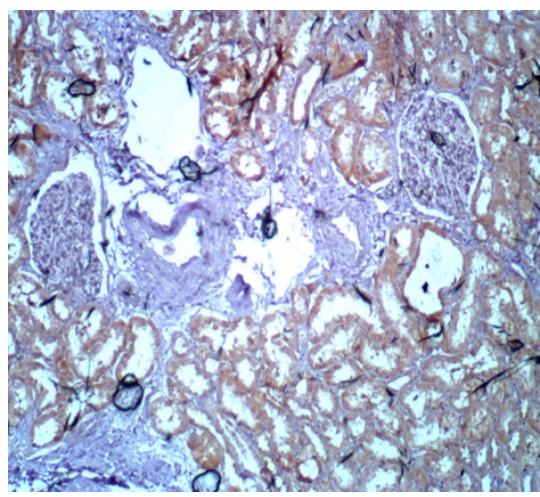

Pic.7 Immunohistochemical staining

Bax protein in a normal renal tissue

Conclusion. It has been shown by this study, that expression of MDM2 and Bcl-2 is significantly upregulated, while Bax is down-regulated in RCC as compared with normal kidney tissue. Intensity of the markers' activities is associated with the tumor pathological and clinical parameters like: stage, grade, lymph node and distant metastases, tumor recurrence and patient survival. Further studies with more patients and longer follow-up will uncover the clinical importance of the evaluated markers in RCC.

Acknowledgment: This study was supported by grant from Shota Rustaveli National Science Foundation \# FR/409/8-338/12.

\section{REFERENCES:}

1. Kernion JB. Reexamination of current staging for renal cell carcinoma. J Urol 2005; 173:680.

2. Kallio JP, Hirvikoski P, Helin H, Luukkaala T, Tammela TL, Kellokumpu-Lehtinen P, Martikainen PM. Renal cell carcinoma MIB-1, Bax and Bcl-2 expression and prognosis. J Urol. 2004; 172: 2158-6.

3. Kontak JA, Campbell SC. Prognostic factors in renal cell carcinoma. Urol Clin North Am 2003; 30: 467-481.

4. Lam JS, Shvarts O, Leppert JT, et al. Renal cell carcinoma 2005: new frontiers in staging, prognostication and targeted molecular therapy. J Urol 2005; 173:1853-1862.

5. Lam JS, Leppert JT, Figlin RA, Belldegrun AS. Role of molecular markers in the diagnosis and therapy of renal cell carcinoma. Urology 2005; 66 (S5): 1-9.

6. Morais C, Pat B, Gobe G, Johnson DW, Healy H. Pyrrolidine dithiocarbamate exerts anti-proliferative and proapoptotic effects in renal cell carcinoma cell lines. Nephrol Dial Transplant. 2006; 21: 3377-88.

7. Morais C, Healy H, Johnson DW, Gobe G. Inhibition of nuclear factor kappa B attenuates tumor progression in an animal model of renal cell carcinoma. Nephrol Dial Transplant. 2010; 25: 1462-74.

8. Noon AP, Polański R, El-Fert AY, et al. Combined p53 and MDM2 biomarker analysis shows a unique pattern of expression associated with poor prognosis in patients with renal cell carcinoma undergoing radical nephrectomy. BJU Int. 2012; 109: 1250-7.

9. Noon AP, Vlatković N, Polański R, et al. p53 and MDM2 in renal cell carcinoma: biomarkers for disease progression and future therapeutic targets? Cancer 2010; 116: 780-90.

10. Oosterwijk E. Tumor markers for renal cell carcinoma. J Urol 2005; 173:2150-2155.

11. Pantuck AJ, Zisman A, Belldegrun AS. The changing natural history of renal cell carcinoma. J Urol 2001; 166:1611-1623.

12. Poulos CK, et al. Preoperative prediction of Gleason grade in radical prostatectomy specimens: the influence of different Gleason grades from multiple positive biopsy sites. Modern Pathology 2005; 18: 228-234.

13. Sakr WA, Scott ML. Potential pathologic markers for prostate chemoprevention studies. Urol Clin N Am 2004; 31: 227-235.

14. Shvarts O, Lam JS, Kim HL, Belldegrun AS. Staging of renal cell carcinoma: current concepts. BJU Int 2005; 95:8-13.

15. Terakawa T, Miyake H, Kusuda Y, Fujisawa M. Expression level of vascular endothelial growth factor receptor-2 in radical nephrectomy specimens as a prognostic predictor in patients with metastatic renal cell carcinoma treated with sunitinib. Urol Oncol. 2013; 31: 493-8.

16. Vatsyayan R, Singhal J, Nagaprashantha LD, Awasthi S, Singhal SS. Nutlin-3 enhances sorafenib efficacy in renal cell carcinoma. Mol Carcinog. 2013; 52: 39-48. 
ЗНАЧЕНИЕ МАРКЕРОВ АПОПТОЗА (МDМ2, ВСL-2 И Вах) В ДИАГНОСТИКЕ ПОЧЕЧНОКЛЕТОЧНОГО РАКА

${ }^{1}$ Национальный центр урологии имени А.Цулукидзе, ${ }^{2}$ Департамент урологии,

${ }^{2}$ Департамент патологии; ${ }^{3}$ Научно-практический центр клинической патологии, Тбилиси, Грузия

\section{РЕЗЮМЕ}

MDM2, BCL-2 и Baх являются протеинами, участвующими в процессе апоптоза. Целью данного исследования явилось изучение роли данных маркеров в диагностике почечно-клеточного рака (ПР). Изучена активность MDM2, BCL-2 и Вах в различных тканевьх структурах, 24 нормальных почек (НП) и 52 - ПР. Проанализированна связь между активностью маркеров и различными клиническими параметрами. Активность MDM2 и BCL-2 была повышена, а активность Bax - понижена при ПР в сравнении с НП. Активность Вах возрастала с увеличением возраста пациентов. Уровень активности маркеров статистически достоверно коррелировал со следующими клиническими параметрами заболевания: стадия, степень дифференциации, региональные и дистальные метастазы; уровень экспрессии маркеров коррелировал с рецидивом заболевания и 5-летней выживаемостью пациентов. Согласно Сох статистическому анализу, риск факторами рецидивирования рака и смерти пациентов являлись размер, стадия и степень дифференциации опухоли.

Аббревиатура: НП - нормальная почка; ПР - почечно-клеточный рак; MDM2 - Регулятор апоптоза (мышиный двойной гомолог 2 минуты 2 (MDM2), также известный как убиквитинпротеинлигаза E3) BAX, также известный как bcl-2-подобный белок 4; Bcl-2-лимфома 2), кодируемая у человека геном BCL2; Bax- (регулятор апоптоза BAX, также известный как bcl-2-подобный белок 4)

\section{ZAKARIA SAKER ${ }^{2}$, OMAR TSINTSADZE ${ }^{2}$, TEIMURAZ JORBENADZE, IRMA JIKIA ${ }^{3}$, LAUR MANAGADZE ${ }^{1}$, ARCHIL CHKHOTUA ${ }^{1}$ \\ IMPORTANCE OF APOPTOSIS MARKERS (MDM2, BCL-2 AND Bax) IN CONVENTIONAL RENAL CELL CARCINOMA}

a.Tsulukidze national centre of Urology, ${ }^{2}$ department of Urology, ${ }^{2}$ department of Pathology;

${ }^{3}$ Scientific and Practical Center of Clinical Pathology, Tbilisi, Georgia

\section{SUMMARY}

The goal of the current study was to analyze the expression of Bcl-2, MDM2 and Bax in benign and malignant renal tissue samples and assess their possible association with different clinical parameters. Prognostic significance of the markers in recurrence-free and cancer-specific survivals has also been evaluated. Activity of MDM2, Bcl-2 and Bax was evaluated in: 24 normal human kidney tissues resected from the patients of different ages (range: 21-80 years), and in 52 conventional RCC samples. Intensity of the markers' expression was compared between the groups and correlation was analyzed with different clinical parameters.

Activity of anti-apoptotic MDM2 and Bcl-2 was significantly elevated while activity of pro-apoptotic Bax was decreased in RCC as compared with normal kidney tissues. Bax expression was positively correlated with patient age. Significant association has been detected between the evaluated markers and cancer clinical parameters like: tumor stage, grade, lymph node and distant metastases. The markers' activity was associates with the tumor morphological features, in particular: presence of tumor necrosis and microvascular invasion. Disease recurrence and 5-year patient survival were associated with the markers' activity. Cox regression analyses have shown that tumor size, pathological stage and grade are the risk factors for disease recurrence and patient death.

Expression of MDM2 and Bcl-2 is significantly up-regulated, while Bax is down-regulated in RCC as compared with normal kidney tissue. Intensity of the markers' activities is associated with the tumor pathological and clinical parameters (stage, grade, lymph node and distant metastases, tumor recurrence and patient survival). Further studies with more patients and longer follow-up will uncover the clinical importance of the evaluated markers in RCC.

Key words: Renal cell carcinoma, apoptosis. 